\title{
Superior antiviral and antiproliferative activity of IFN-beta vs. IFN-alpha in primary ATL cells occurs downstream of STAT1 signaling
}

\author{
Ricardo Khouri ${ }^{1,2}$, Gilvaneia Silva-Santos ${ }^{2}$, Lourdes Farre ${ }^{2}$, Achilea Bittencourt ${ }^{3}$, Anne-Mieke Vandamme ${ }^{1,4}$, \\ Johan Van Weyenbergh ${ }^{1,2,5^{*}}$
}

From 16th International Conference on Human Retroviruses: HTLV and Related Viruses

Montreal, Canada. 26-30 June 2013

Adult T-cell leukemia (ATL) is an aggressive $\mathrm{CD} 4^{+} \mathrm{CD} 25^{+}$ leukemia with poor prognosis, which usually develops several decades after HTLV-1 infection. In contrast to HIV-infection, the treatment of HTLV-1-associated diseases rely on a limited number of drugs. For ATL, combination therapy with IFN-alpha+AZT has shown clinical benefit in the non-lymphoma subtypes. Type I IFNs (IFN-alpha/beta) are essential cytokines with proved anticancer and antiviral action in vitro and in vivo. Nonetheless, their mechanisms of action in HTLV-1 infection remain unclear and a side-by-side comparison of both type I IFNs has not been performed in ATL. We show, in short-term culture of primary mononuclear cells from ATL patients, that both IFNs cause increased apoptosis, exert an anti-proliferative and antiviral effect, and decrease pro-inflammatory cytokine levels. However, IFN-beta treatment was significantly more effective in inhibiting viral p19 protein levels and lymphoproliferation, as compared to IFN-alpha. This pronounced effect of IFNbeta was explained by an induction of a higher number of known IFN-stimulated genes and antiviral genes by microarray analysis ( 76 vs. 26 genes were selected with $p<0.001$ and $>2$-fold difference vs. control). In PBMCs from healthy donors, ATL patients as well as in HTLV-1infected cell lines, both IFNs have comparable activity in phosphorylating STATs 1 through 5 (PhosFlow), although phospho-STAT1 levels were up to tenfold higher than phospho-STAT2 through 5. This predominant STAT1mediated antiviral gene signature was confirmed by Ingenuity Pathway analysis. In conclusion, our data suggest the

\footnotetext{
* Correspondence: johan@bahia.fiocruz.br

'Rega Institute for Medical Research, Department of Microbiology and Immunology, K.U.Leuven, Belgium

Full list of author information is available at the end of the article
}

superior antiviral and antiproliferative activity of IFN-beta vs. IFN-alpha occurs downstream of STAT1 signaling.

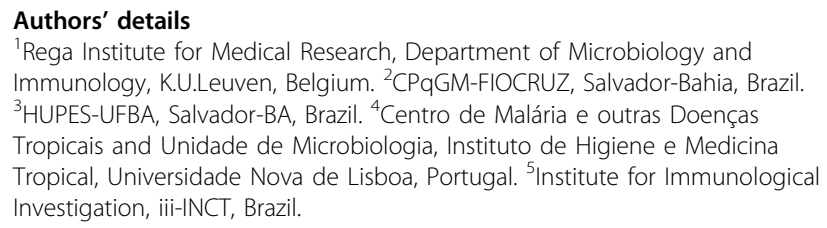
Immunology, K.U.Leuven, Belgium. ${ }^{2}$ CPqGM-FIOCRUZ, Salvador-Bahia, Brazil. ${ }^{3}$ HUPES-UFBA, Salvador-BA, Brazil. ${ }^{4}$ Centro de Malária e outras Doenças Tropicais and Unidade de Microbiologia, Instituto de Higiene e Medicina Tropical, Universidade Nova de Lisboa, Portugal. ${ }^{5}$ Institute for Immunological Investigation, iii-INCT, Brazil.

Published: 7 January 2014

doi:10.1186/1742-4690-11-S1-022

Cite this article as: Khouri et al: Superior antiviral and antiproliferative activity of IFN-beta vs. IFN-alpha in primary ATL cells occurs downstream of STAT1 signaling. Retrovirology 2014 11(Suppl 1):O22.

\section{Submit your next manuscript to BioMed Central and take full advantage of: \\ - Convenient online submission \\ - Thorough peer review \\ - No space constraints or color figure charges \\ - Immediate publication on acceptance \\ - Inclusion in PubMed, CAS, Scopus and Google Scholar \\ - Research which is freely available for redistribution \\ Submit your manuscript at www.biomedcentral.com/submit}

